LA-UR- $-82-2797$

DE83 000608

TITLE: IMPLEMENTATION OF THE ACTIVE NEUTRON COOINCIDENCE GOLLAR FOR THE YERIFICATION OF UNIRRADIATED PWR AND BWR RUEL ASSEMBLIES

AUTHOR(S):

h. U. Menlove and A. Kedda

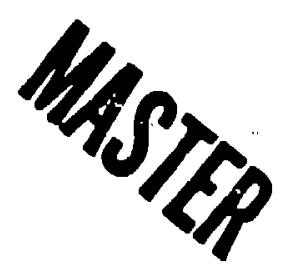

SUBMitTED to: International Symposfum on Recent Advaices

in Nuclear Materials Safeguards

Vienna, Austria

November 8-12, 1982 


\section{IMPLEMENTATIOH OF THE ACTIVE NEUTRON COINCIDENCE COLLAR FOR THE VERIFICATION OF UNIRRADIATED PWR AND BWR FUEL ASSEMBLIES*}

\section{ABSTRACT}

An active neutron interrogation technique has been developed for the measurement of the ${ }^{235} U$ content in fresh fuel assemblies. The method employs an AmLi neutron source to induce fission reactions in the fuel assembly and coincidence counting of the resulting fission reaction neutrons. When no interrogation source is present, the passive neutron coincidence rate gives a measure of the ${ }^{238} U$ by the spontaneous fission reactions. The system can be applied to the fisslle content determination in fresh fuel assemblies for accountabllity, criticality control, and safeguards purposes.

Fleld tests have been perfumed by International Atomic Energy Agency (IAEA) staff using the Coincidence Collar to verify the ${ }^{235} U$ content in 1ight-water-reactor fuel assemblies. The results gave an accuracy of $1-2 \%$ in the active mode $\left({ }^{235} U\right)$ and $2-3 \%$ in the passive mode $\left({ }^{238} U\right.$, under field conditions.

\section{INTRODUCTION}

Determination of the fissile content in unirradiated fuel assemblies is important for nuclear material accountability and

*Thts work was partially supported by the US Department of Energy/Office of Safeguards and Securlty and the Program of Technical Assistance to IAEA Safeguards. 
safeguards. Measurements are needed at the fuel fabrication facllity and at the reactor site when the fuel shipment is recetved or the inventory is verified.

This paper describes the implementation of the active neutron Colncidence Collar[1] that has been developed for measurement of the ${ }^{235} \mathrm{U}$ content in fresh fuel assemblies. The method employs an AmLi neutron source to induce fissior reactions in the fuel assembly aild coincidence counting of the resulting fission reaction neutrons. This coincidence counting eliminates the undesired neutron counts from the random Anili interrogation source and room background neutroris. When no Interrogation source is present, the passive neutron coincidence rate gives a measure of the ${ }^{236} U$ through the spontaneous fission reactions.

Previous work $[1,2]$ has demonstrated that the Coincidence Collar can detect fuel rod substitutions in the interior of the fuel assembly by using mockup fuel assemblies with removable rods. The present paper gives the results of using the coinctdence Collar to verify the fissile content in bolling-waterreactor (BWR) and pressurlzed-water-reactor (PWR) fuel assemblies.

\section{SYSTEM DESCRIPTION}

The Colncidence coliar consists of three banks of $3_{\text {He }}$ tubes and an AmLI source imbedcled in a high-density polyethylene body as shown in Figs. $Y$ and 2 . The $183^{3}$ He neutron detector tubas (4 atm pressure) are $2.54 \mathrm{~cm}$ in diameter and $33 \mathrm{~cm}$ long 
(active length). For the measurement of BWR fuel elements, the sides of the detector are adjusted inward.

The polyethylene body performs three basic functions in the system: (1) genera? mechanical support, (2) interrogation source neutron moderation, and (3) slowing down of induced fission neutrons prior to their detection in the ${ }^{3}$ He tubes. For inspection applications, it is desirable to make the system portable. The weight of the present detector head is $225 \mathrm{~kg}$.

The AmLi interrogation source produces random neutrons (not time correlated) with an average energy of $2300 \mathrm{keV}$. The present Coincidence Collar uses a source fabricated by Monsanto Research Corp. (Model 2724-BT) with a yteld of $4.5 \times 10^{4} \mathrm{n} / \mathrm{s}$.

The electronics used with the Colncifence Collar are the same as that used with the High-Level Neutron Coincidence Counter (HLNCC).[3] This unit contains high-and low-voltage power supplies, six amplifier-discriminator lines, a microprocessor, and shift-register[4] coinctidence logic. The electronic unit is directly interfaced to an HP-97 programable calculator. The microprocessor is used to read out the run time, total counts, reals plus uccidental counts, and accidental counts to the HP-97. The Hi-97 is used to reduce the data using the software program selected by the operator.

The complete assay system is shown in Fig. 3, including the detector body, electronic unit, HP-97 calculator, and support cart. For applications, the cart is moved next to a fuel assembly, as shown If FIg. 3. The back detector bank of the unit 
is hinaed (see Fig. 1) to ald in positioning the system around the fue, issembly.

\section{FIELD TEST RESULTS}

\subsection{PWR Assembly Verification}

To evaluate the performance of the Colncidence Collar under in-plant conditions, measurements were performed by the IAEA and Los Alamos National Laboratory staff at both PWR and BWR fuel fabrication facilities. The measurements for P:iR fuel assemblies took place at the Franco-Belge de Fabrication de Comblistibles (FBFC) factlity in Dessel, Belglum.[2]

The fuel assemblies avallable for measurement at the FBFC faclitity included a range of ${ }^{235} \mathrm{U}$ enrichments from $1.8-3.2 \%$. For all of the measurements, the elements consisted of a 17- by 17-rod array with 25 open hoies for control rod insertion. Most of the fuel assemblies were instie plastic protective bags, and about half the assemblies had an additional layer of cardboard around the plastic bag.

The measurements on each assembiy were performed using several runs of $200 \mathrm{~s}$ each, depending on avallable time. No personnel were required to be in attendance during the cyclic measurements. For each assembly, the measurements were performed with and without the AmL1 source to obtain both the ${ }^{235} \mathrm{U}$ and ${ }^{238_{U}}$ values. Sixteen different fuel assemblies were messurst.

The response curve, shown in F1g. 4, is not saturated and continues to increase as the enrichment increases through the 
nomal range of light-water-reactor (LWR) fuel. The statistical precision $(\gamma \sigma)$ is $0.7 \%$ arid relative loading variations as small as $1.9 \%$ can be detected in a measurement time of $1000 \mathrm{~s}$. Longer measurements can further reduce the statistical uncertainties.

The measurements at the PWR fuel fabrication factlity had the following operational advantages: (1) no fuel assembly handling or movement was required of the plant operator, (2) the fuel assemblies were not touched during the measurements, and (3) the protective plastic bagging and cardboard were not removed from the fuel assemblies for the measurements.

\subsection{BWR Fuel Assembly Zerification}

The field test[5] for BWR fuel assemblles was performed at the ASEA-Atom Fabrication Facility in Vaesteraas. Sweden. For the mensurements, ASE4-Atom furnished a serles of iwo different types of BWR production fuel assemblies as well as a full-size test assembly that could be reloaded to achleve different test configurations. The parameters that were changed inciuded the enrichment. spatial configuration, number of rods, and the gadoIintum (burnable poison) content.

\subsubsection{Response vs BWR Side Orientation}

There are nomally several different enrichmenes in a single BWR fuel assembly and these are nonsymmetric as viewed from the different sides. Ts see if this affects the response, the assembly was measured ofi all four sides and the results were 
compared. No differences were observed in the responses within the measurement prectsion of $\pm 1 \%$.

Previous measurements[1] using a BWR mockup assembly at Los Alamos had indicated that the response from the coincidence Collar was independent of the position of rods of different enrichments in the assembly. However, the measurement does depend on the number and position of the gadolinium rods. Because the gadolintum rods are always placed in the interior of the BWR assemblies, roughly equidistant from each other, the measured response was the same for all sides of the fuel assembly with the gadolintum rods in place.

3.2.2. Response vs Enrichiment or ${ }^{235} U$ Content

The Coincidence Collar measures the ${ }^{235} \mathrm{~J} \mathrm{or}{ }^{238} \mathrm{~J}$ content per unit length, which is proportional to the enrictment for a given type of assembly. The sampled region is approximately $400 \mathrm{~mm}$ long centered in the midplane of the detector body. If the edge of the detector body gets closer than $20 \mathrm{~cm}$ to the top or bottom onds of the fuel region, the measured response will decrease because of end leakage or the rielitrons. Any region selected inside these end reglons should give a cunstant counting rate if the $235_{1}$, loading and $\mathrm{Gd}_{2} \mathrm{O}_{3}$ loading are uniform.

When an overhead crane is avallable for scanning the fuel assombly through the detector. tire entire assembly can be samplod. The measurement time is the same for the scinning or stationary modes for equivalent statistical prectsion. If the scanning mode is user, the calibration curve should be obtalned 
in the same manner to take frito account the end losses as the assembly enters and leaves the detector.

The results of the measurements are 11sted in Table I for the active neutron case using the Coincidence Collar. Typical1y, five runs of $200 \mathrm{~s}$ each were used to obtain the results: however, some of the elements were measured for longer periods corresponding to lunch breaks and overnight runs. The average net colncidence response and the scatter (standard deviation, S) about the mean are iisced in Table I. The statistical precision for the BWR assamblies riss $1.0 \%(1 \sigma)$ for $1000 \mathrm{~s}$ of measurement time.

Figure 5 shows the coincidence response as a iunction or enrichment for the active case. It can be seen that the response increases with enrichment and the response is not saturated. This is due, in part, to fast neutron multiplication. There is no significant variation as a function of assembly storage location and the proximity of neighboring assemblies.

The gadolintum loading in the BWR assemblies decreases the observed response. Also, the gadolinium concentration is higher in the bottom half of the fuel assemblies than in the top. The two curves shown in Fig. 5 correspond to the top and bottom regions. The separation in the two curvas is a measure of the numper of gadolintum-loaded rods.

\subsubsection{Passive Risults}

When the AnLt source is removed fiom the detector, the passive colncidence rate 1 s proportional to the ${ }^{238_{U}}$ mass via 
the spontaneous fission neutrons. For the $8 \times 8$ BWR assemblies, the urantum mass and the enrfchment did not change enough to significantly change the passive response, which was 3.18 counts/s. Because this is only a small fraction of the active response, which ranges from 80-100 counts/s, the passive rate was not measured for each of the assemblies, and the constant rate $(3.18)$ was subtracted from the active rate to get the net active rate.

When the uranium mass or rods are removed from the assembly, the passive rate drops because of the reduction in the $238_{U}$ source strength and because of the reduction in the fast-neutron multiplication and the decrease in the reflection of neutrons from the top and bottom of the measurement zone.

The statistical precision for the $8 \times 8$ assembly was $1.8 \%$ for $1000 \mathrm{~s}$ of run time in the passive mode. The gadolinium rods do not affect the passive measurement because the signal is from fast fission neutrons, and the thermal neutron absorber (gadointum) has no effect.

\section{2:4. Effects of Gadolinium Rods and Cadmium Shest}

To evaluate the effect of the rods containing gadolintum on the active response, the $8 \times 8$ mockup assembly was changed to contain 5, 3, and 0 gadolinium rods. In each case, the gadoilntum rod was replaces by a rod containing the same $235 \mathrm{~J}$ enrichment (3.17\%) but without gadolinilum. The results of the active measurements are shown in Fig. 6, where we see that one 
gadolinium $\left(24.4 \mathrm{wt} \mathrm{Gd}_{2} \mathrm{O}_{3}\right)$ rod reduces the active response by about $5 \%$.

The perturbation on the measurement from the $\mathrm{Gd}_{2} \mathrm{O}_{3}$ can be mostly eliminated by using thin cadmium sheet liners $10.4 \mathrm{~mm}$ thick) on the inside surface of the sample chamber. The cadmi um removes the thermal neutrons from the interrogation flux and thus the ther.nal-neutron poison $\left(\mathrm{Gd}_{2} \mathrm{O}_{3}\right)$ has no significant effect. The bottom curve in Fig. 6 shows that there is little difference in the responses with 0 or $5 \mathrm{Gd}_{2} \mathrm{O}_{3}$ rods when the cadmium sheet is in place.

However, the cadmium reduces the signal rate and thus the measurement time to reach a given precision is increased. For example, the standard deviation with cadmium is $4.0 \%$ in $1000 \mathrm{~s}$ as compared with $1.0 \%$ in $1000 \mathrm{~s}$ with no cadmium. Because the cadmium increases the required measurement time, it should only be used as a potential check on the operator's deciared gadoinium content and not for rout: ne use.

Because the gauslinfum loading is greater in the bottom than the top half of the assembiy, the bottom-to-top ratio gives a second potential check on the gadolinium content. For example, If the $\mathrm{Gd}_{2} \mathrm{O}_{3}$ were removed to give a higher reading for the average ${ }^{235} U$ enrichment, then che bottom and top measuremeits would be the same as opposed to the normal difference of $25 \%$ as shown in Fig. 5. 


\subsubsection{Production Assembly Results}

Two types of production assemblies were avallable for the tests; type $1(T \cdot 1)$ containting six rods with 4.4 wt\% $\mathrm{GC}_{2} \mathrm{O}_{3}$ and type $2(T \cdot 2)$ containing four rods with 2.0 wt\% $^{\mathrm{Gd}_{2} \mathrm{O}_{3}}$. Several of these assemblies were measured as shown in Table I. The responses showed a scatter of $21 \%$, which is consistent with the statistical expectation; for measurement times of 800-1000 s.

The cilibration results from the mockup assembly were used to assay the production assemblies. A least squares fit to the data for the top and bottom zones established the two calibraticn curves shown in Fig. 5. The measured data from the production assemblies were then corrected for the differences in $\mathrm{Gd}_{2} \mathrm{O}_{3}$ using $\mathrm{Fig} .6$, and the responses were fit to the mockup calibration curves to determine the ${ }^{235} U$ content. The average difference between the collar assay value and the tag value was $0.6 \%$ for the $T \cdot 1$ assemblies and $0.35 \%$ for the $T \cdot 2$ assemblies.

\subsection{Exxon Nuclear, Richland, Washington - Implementation}

To qualify the Colncidence Collar for future inspection applications, an exercise was performed at the Exxon Nuclear fabrication factlity in Richland, Washington. The measurements Included both BWR and P.IR production assemblies. The BWR assembltes were all $8 \times 8$ rod arrays containing elght gadolinium rods (4.0 wt\% gadolinium metal) and two water-filled rods. The PWR assembltes were standard 17- by 17-rod arrays with 25 empty channels. 
The prevfous tests and evaluations using the collar were to collect data and establish calibration curves. For inspector application, the calibration parameters are entered into the software and a calibration function is used to calculate the loading density $\left(\mathrm{g}^{235} \mathrm{U} / \mathrm{cm}\right)$ and the ${ }^{235} \mathrm{U}$ enrichment. This calculation and the error analysis are also done in the HP-97 software program.

\section{FIEI.D CAL IBRATION}

Calibration of the Coincidence Counter in an absolute sense is difficult because of the complexity and costs of "standard" fuel assemblies. Normalization procedures have been developed[1] to reduce the requirements for physical standards.

\subsection{Parameter Sensitivity}

The Coincidence Collar has been designed to make the results insinsitive to variations in the assembly, such as

(a) number and position of open channels for reactor control rods,

(b) mixture and position of fuel rods with different enrichnents,

(c) angular orientation of the fuel assembly in the Coincidence Collar,

(d) nominal differences in fuel pellet density, and

(e) any protective bagging or cardboard on the outside of the fuel assembly. 
The Coincidence Collar is somewhat sensitive to

(a) stainless steel vs Zircaloy cladding,

(b) large differences in fuel pellet diameter, and

(c) size of the fue!-rod array.

\subsection{Calibration Normalization}

For most applications, it will not be possible to have physical standards avallable at the factlity being inspecter, so it will be necessary to relate the inspection measurement to calibration messurements at a "host" facllity that has the same or simflar type fuel assemblies. The AmLt neutron source can be used as a calibration nomalization source[1] to bridge the distance and time between the actuar calibration and the field Inspection.

There are two detector configurations: wide for PWR and liotrow for BWR. The Coineldenes Collar must always be callorated in the same configuration as it is to be used, because the efficiency is different for the two cori'igurations.

\subsection{Calibration Curve Function}

The resporse of the Colnctdence Collar is nonlinear, primarlly because of neutron self-shielding and fission neutron multiplicition. Thus, it is necessary to use several fuel assembly standards with different fisstle loadings to establish a calfuration curve. The callbration data collected at FBFC and ASEA-Atom for PWR and BWR assemblies, respectively, were fit 
with quadratic and power function calibration curves. The best fit was obtained with a power function of the form

$$
M=a R^{b}
$$

where $M$ is the fissile content $(235 \mathrm{~g} / \mathrm{cm}), R$ is the corrected real coincidence rate, and a and $b$ are the fitting constants. The advantage of using the mass per unit length rather than enrichment is that one fuel assembly type (for example, a 17 by 17 array) can be related to other fuel assembly geometries (for example, 15 by 15 array) of the same type.

Figure 7 shows the least squares fit of the power function callbration curve to the BWR data. Also shuwn are the $95 \%$ confidence intervals obtained from the fit.

This calibration function was used tn measure "uriknown" fuel assembiles at the Exxon Nuclear fabrication facllity. The results of the measurements are given in Table II, where the calfbration parameters had been obtalned from the dati previously collected at FBFC and ASEA-Atom. The agreement is within the statistical expectation of 1-2\%.

\section{CONCLUSIONS}

For relatfve measurements of similar fuel assemblies in a factlity, the overall accuracy $(10)$ for ${ }^{235} U$ content is $1-2 \%$. Fol absolute measurements using calfbration parameters from other faclifties and fuel assemblies, the accuracy should be in the range of $2-4 \%$, depending on how closely the standards match 
the unknowns and how carefully the callibration has been performed. The calibration curve shape parameters should be the same for all BWR and PWR fuel assemblies and only the normaltzation constant need be adjusted for different equipment and faclifities.

ihe impact on the nuclear facilities has been minor, and no problems or negative col. ents have been observed. There is no need to touch the fuel assemblies, and the faclifty operator can position the coilar, if desired.

The combined passive and active measurements giving both ${ }^{238} U$ and $235 U$ content make the verification very tamper resistant. The equipment can be used with little or no callbration effort to give a relative measurement or an attribute check, and with careful calibration, it can give a varlable measurement. The equipment has been demonstrated to be suttable for use in the verification of BWR and PWR fuel assemblies. In-plant neutron backgrounds do not adversely affect the measurement because the neutron coincioence counting essentially eliminates the background neutrons.

Future efforts will be directed toward the posstble use of the Colncidence Collar for WWER, MTR, and CANDU type fuel assemblies a: well as storage trays of fuel rods. Comfuter calculations will be performen to extend the range of the calibration curves and to reduce the number of physical standards required. 


\section{REFERENCES}

[1] MENLOVE, H. O., "Description and Performance Characteristics for the Neutron Coincidence Collar for the Verification of Reactor Fuel Assemblies," Los Alamos National Laboratory report LA-8939-MS (ISPO-142) (1981).

[2] BEETS, C., et 1.. "Optimization of NDA Measurements in Field Conditions for Safeguards Purposes," Third Progress Report - Contract RB/2274, BLG 553 (1982).

[3] KRICK, M. S., et al., "The High-Level Neutron Coinsidence Counter (HLNCC): Users' Manual," Los Alamos Sclentific Laboratory report LA-7779-M (ISPO-53) (1979).

[4] SWANSEN, J. E., et a1.. "Shift-Register Coincidence Electronics System for Thermal Neutron Counters," Los Alamos Sctentffic Laboratory report LA-8319-MS (1980). Also in Nuc 1, Instruin. Methods 176 (1980).

[5] MENLOVE, H. O.. et al., "Ffeld Test and Evaluation of the IASA Colncidence Collar for the Measurement. of Unirradiated BWR Fuel Assemblies," Los Alamos National Laboratory draft report LA-9375-MS (ISP0-174) (1992). 


\section{FIGURE CAPTIONS}

Fig. 1. Schematic diagram of Colnctdence Collar showing the AmL 1 nieutron source, the 3 He detector banks, and the poly- thylene moderator material. The detector bank opposite the neutron source pivots open on the hinge to accommodate PWR, BWR, or HWR fuel assemblies.

Fig. 2. Colncidence Collar detector head with AmLi neutron source for active assay of LWR fuel assemblies.

Fig. 3. The Coincldence Collar in measurement position around a mockup PWR fuel assembly. showing HEC-100 electronics, HP-97 calculator, and support cart.

F1g. 4. Active neutron colncidence response as a function of enrichment for 17 by 17 PWR assemblies.

Fig. 5. The results from the production assembly measiarements compared with the callbretion curves obtalned from the mockup assembly.

Fig. 6. Colncldence rate as a function of the number of $\mathrm{Gr}_{2} \mathrm{O}_{3}$ rods both with (bottom curve) and without (top curve) a cadmfum iner on the inside of the collar.

F1g. 7. Power function calluration curve for BiNR fusl asseinblies showing $95 \%$ confidence 1 intts. 


\section{TABLE :}

ACTIVE ASSAY OF BHR FUEL ASSEMBLIES

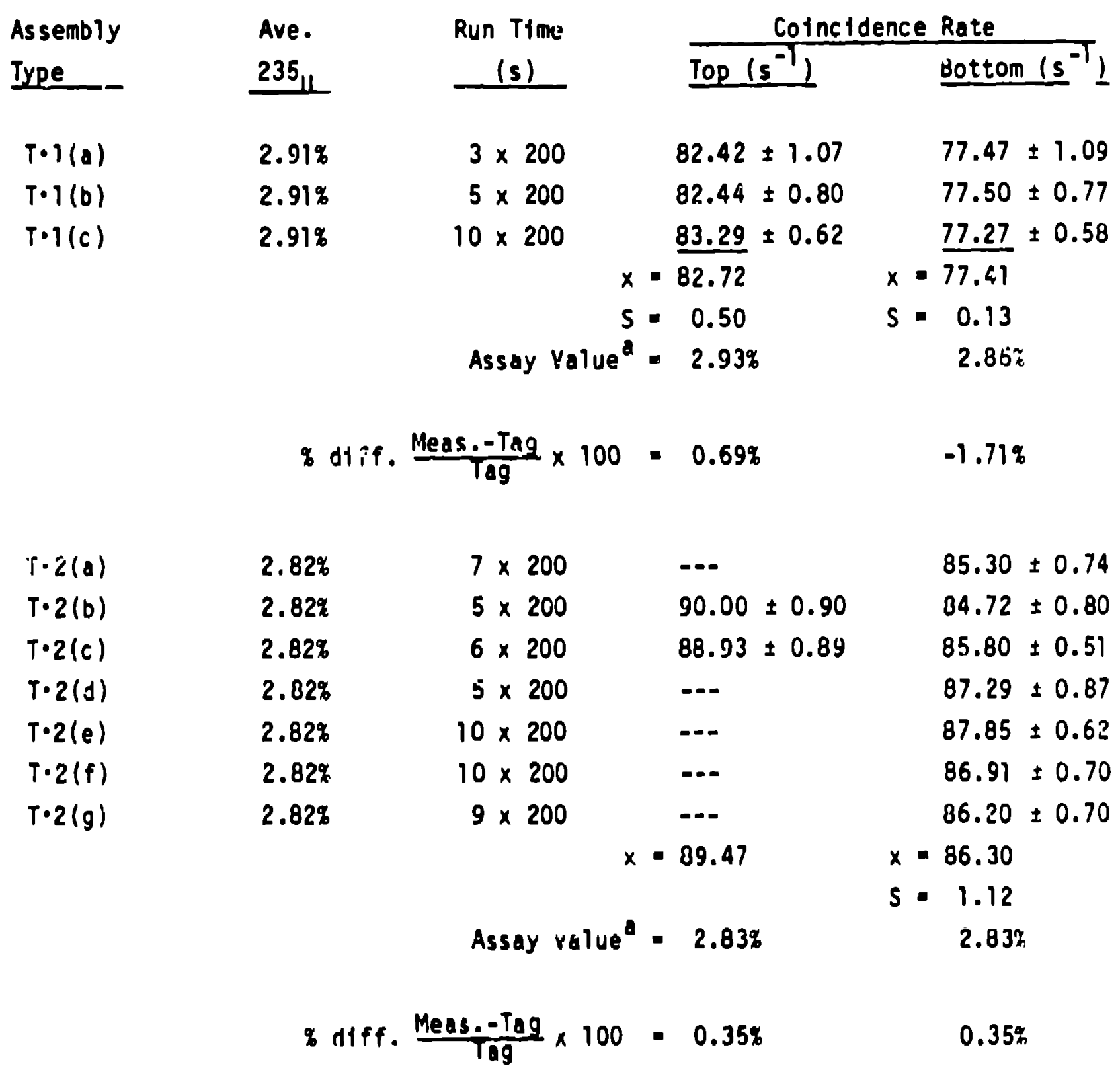

Assay value from callbration curve form mockup assembly after correction for differences in $\mathrm{Gd}_{2} \mathrm{O}_{3}$ loading. 
TABLE II

ACTIVE ASSAY RESULTS AT EXXON NUCLEAR

\begin{tabular}{|c|c|c|c|c|c|c|}
\hline $\begin{array}{l}\text { Assembly } \\
\text { Type }\end{array}$ & $\begin{array}{c}\text { Run Time } \\
(\mathrm{s}) \\
\end{array}$ & $\begin{array}{r}\text { Meas } \\
235 \mathrm{U} \\
\end{array}$ & $\frac{\text { ass }}{2235(1)}$ & $\frac{T a g}{1 g^{235} \mathrm{U} / \mathrm{c}}$ & e & $\begin{array}{c}\text { Difference } \\
(\mathbf{z})\end{array}$ \\
\hline BWR 1 & $12 \times 200$ & 14.90 & 3.23 & 14.92 & 3.236 & 0.1 \\
\hline BWR 2 & $7 \times 200$ & 14.88 & 3.23 & 14.92 & 3.236 & 0.2 \\
\hline PWR 1 & $10 \times 200$ & 38.90 & 3.54 & 40.0 & 3.645 & 2.8 \\
\hline
\end{tabular}




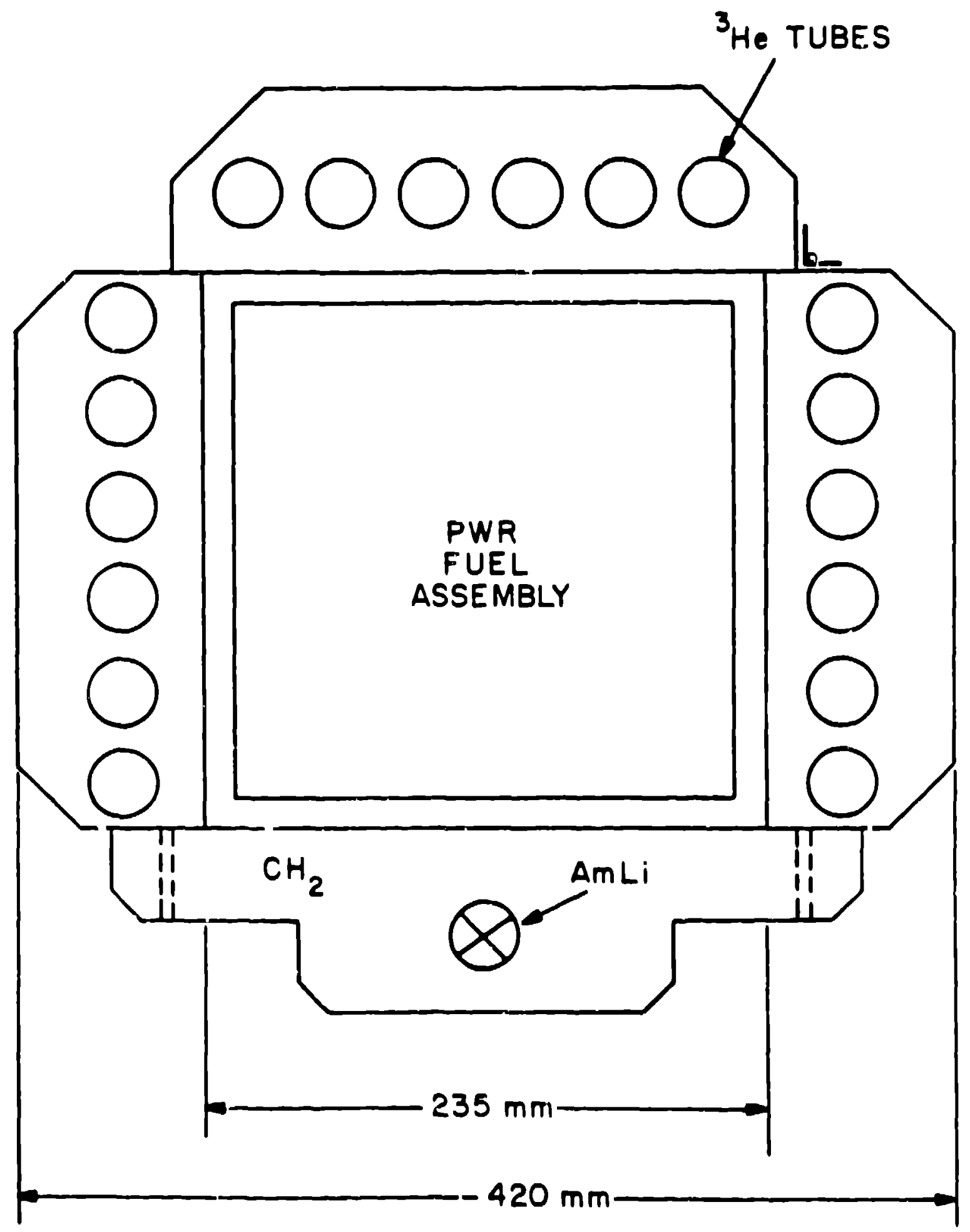

F1g. 1. Schematic diagram of Colnctdence Collar showing the AmLl neutron source, the 3He detector banks, and the polyethylane moderator material. The detector bank opposite the neutron source pivots open on tive hinge to accommodate PWR, BWR, or HHR fuel assemblies. 


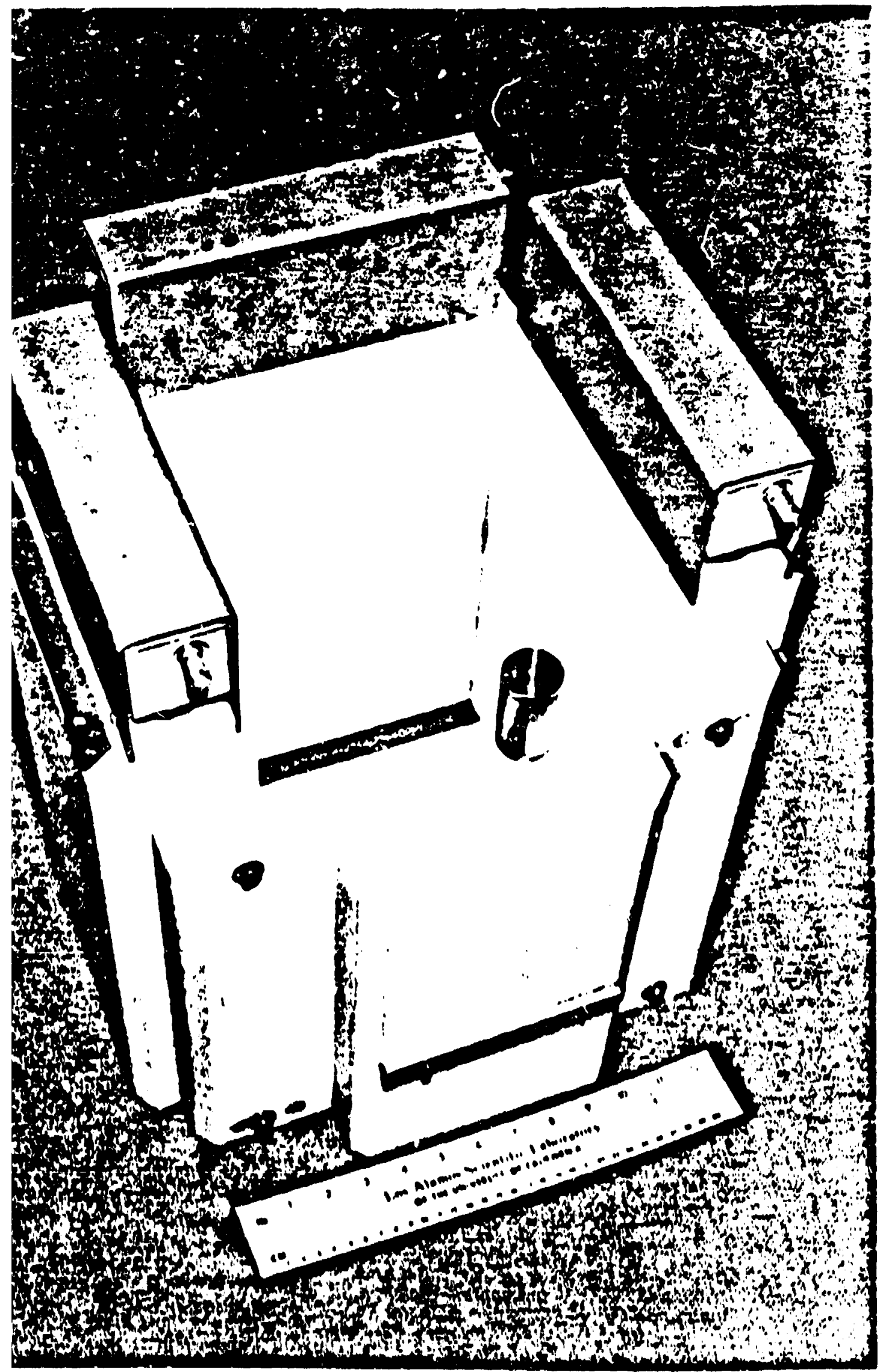

Incldence Collar detector head with Mall neutron source for 


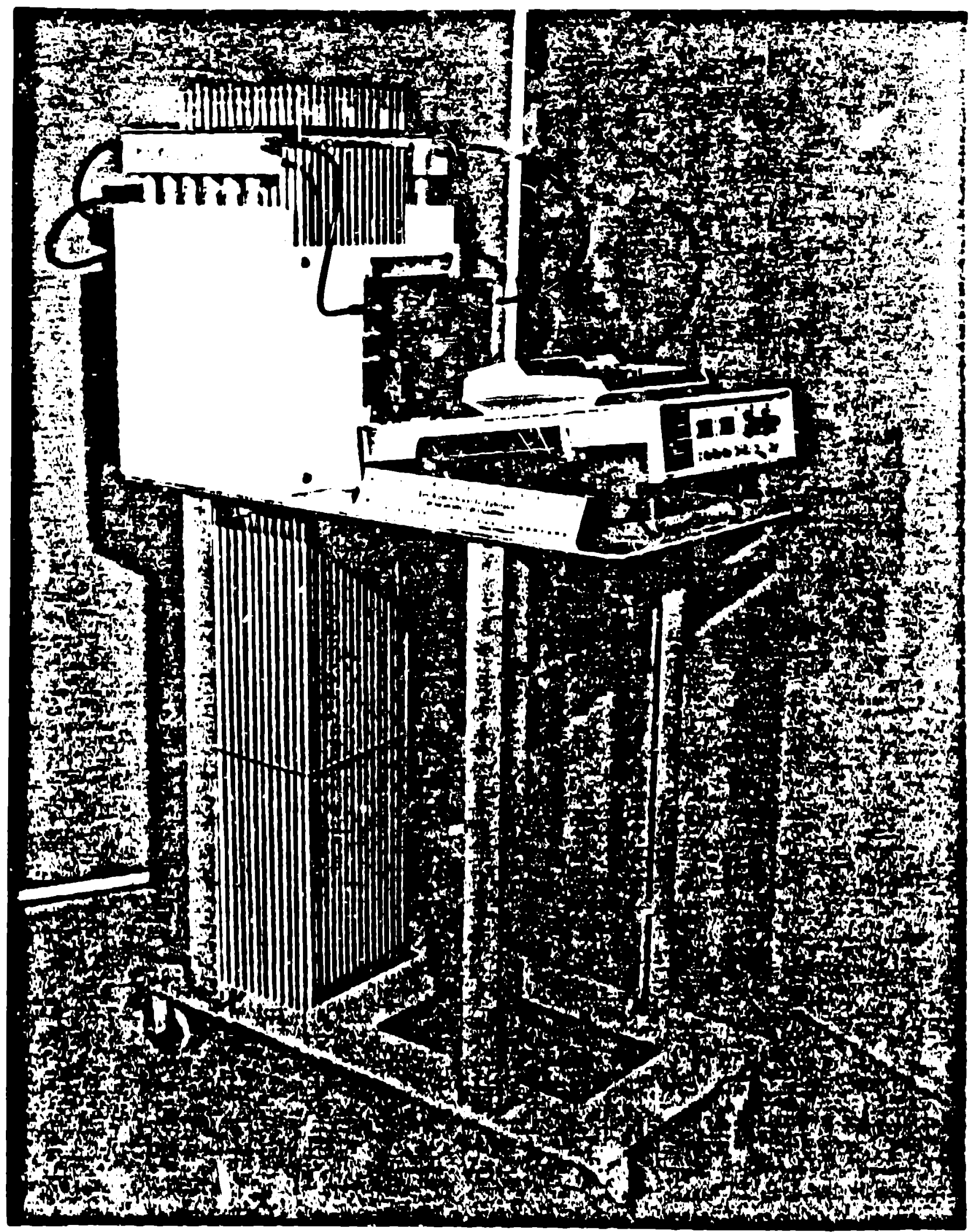

F19. 3. The Colncidence Collar in mesurement positt on sround a mockup PWR fivi assembly, showing : EC- 100 electrontcs, HP-97 colculator. and support cart. 


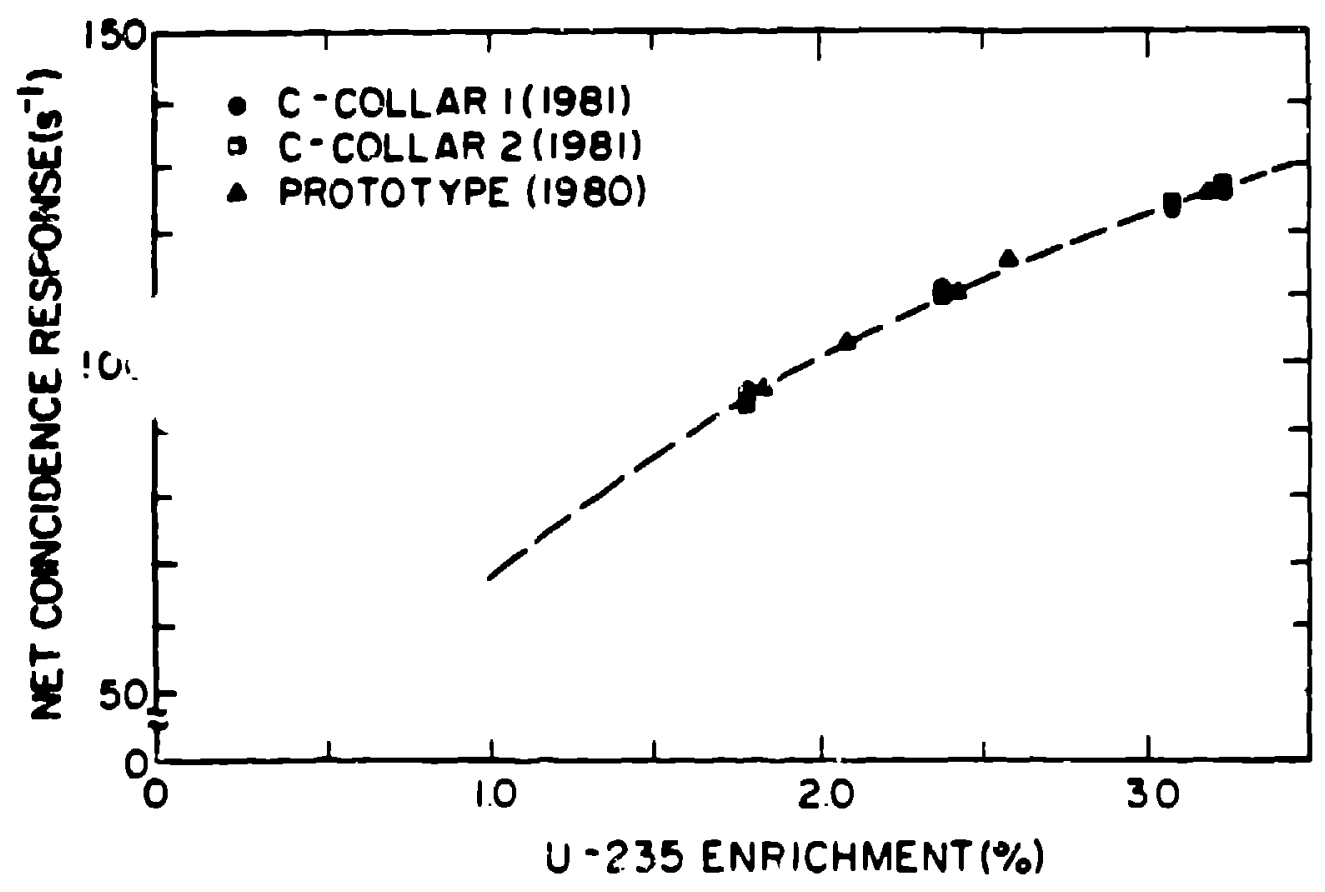

Fig. 4. Active neutron coincidence response as a function of enrichment for 17 bv 17 PWR assemblies. 


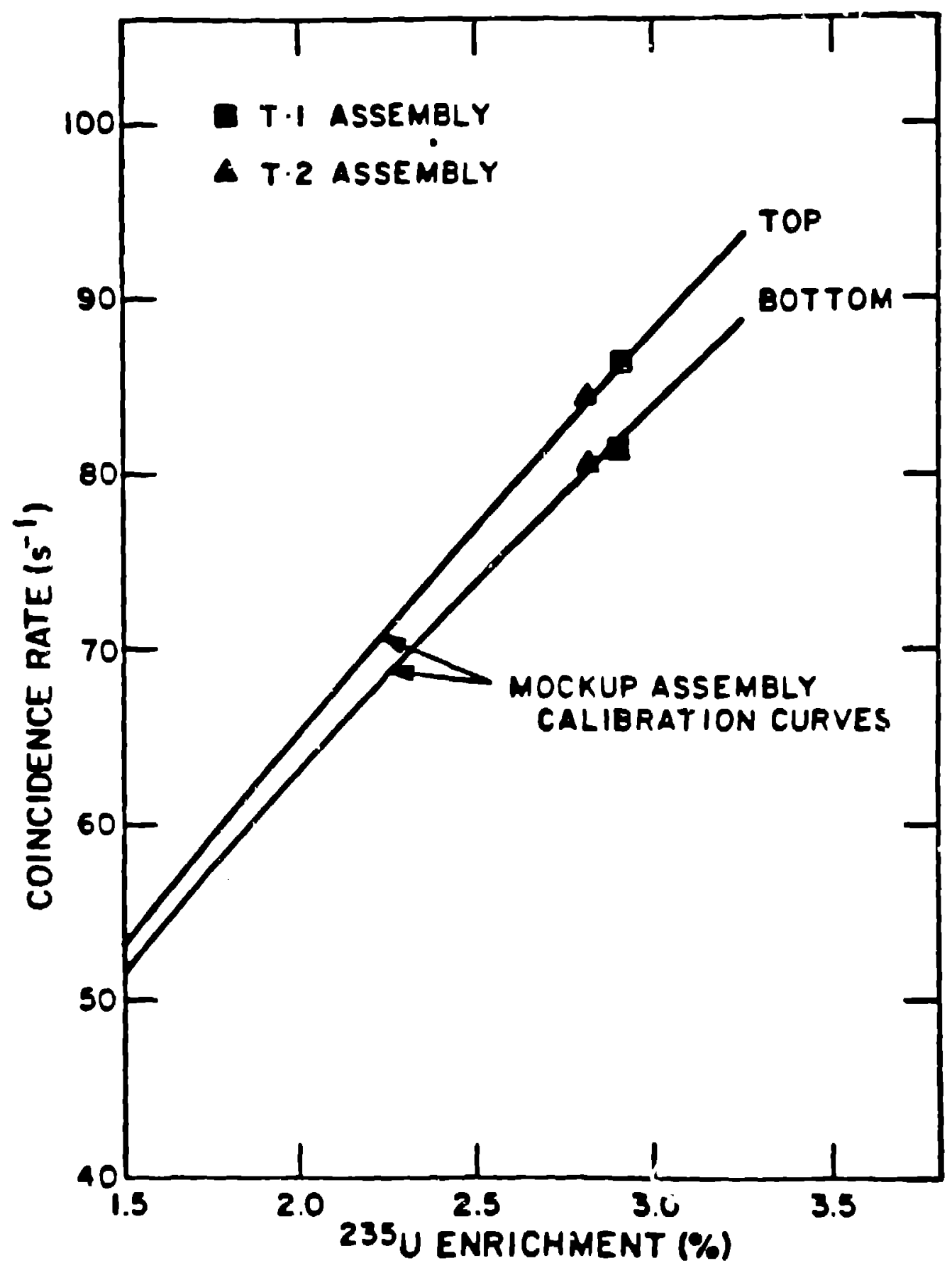

Fig. 5. The results from the production assembly measurements compared with the calfbration curves obtained frnin the mockup assembly. 


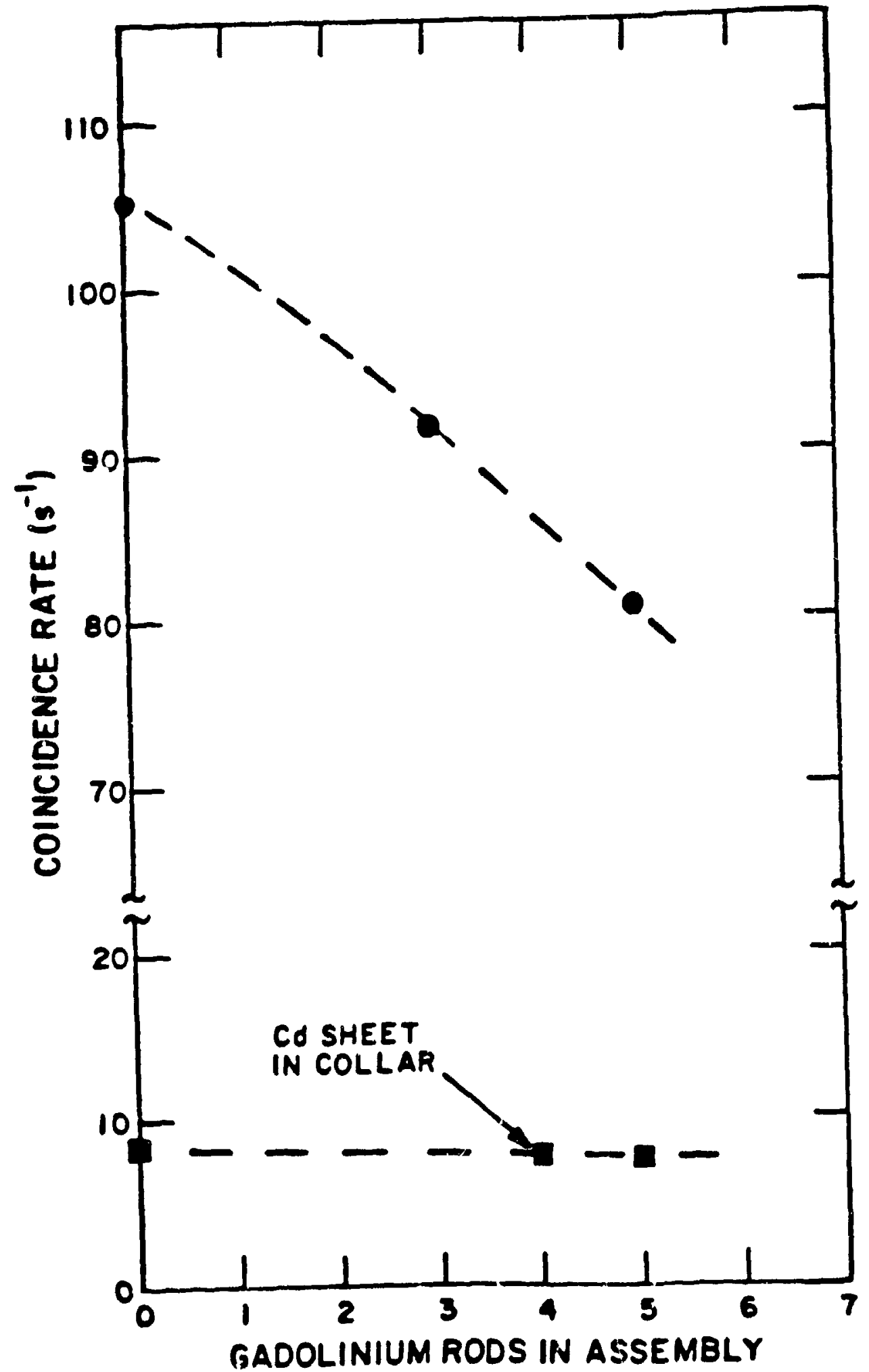

Fig. 6. Coincidence rate as function of the number of $\mathrm{Gd}_{2} \mathrm{O}_{3}$ rods both with (bottom curve) and without (top curve) a cadmium iner on the inside of the collar. 


\section{C-Collar-3 BWR Calibration}

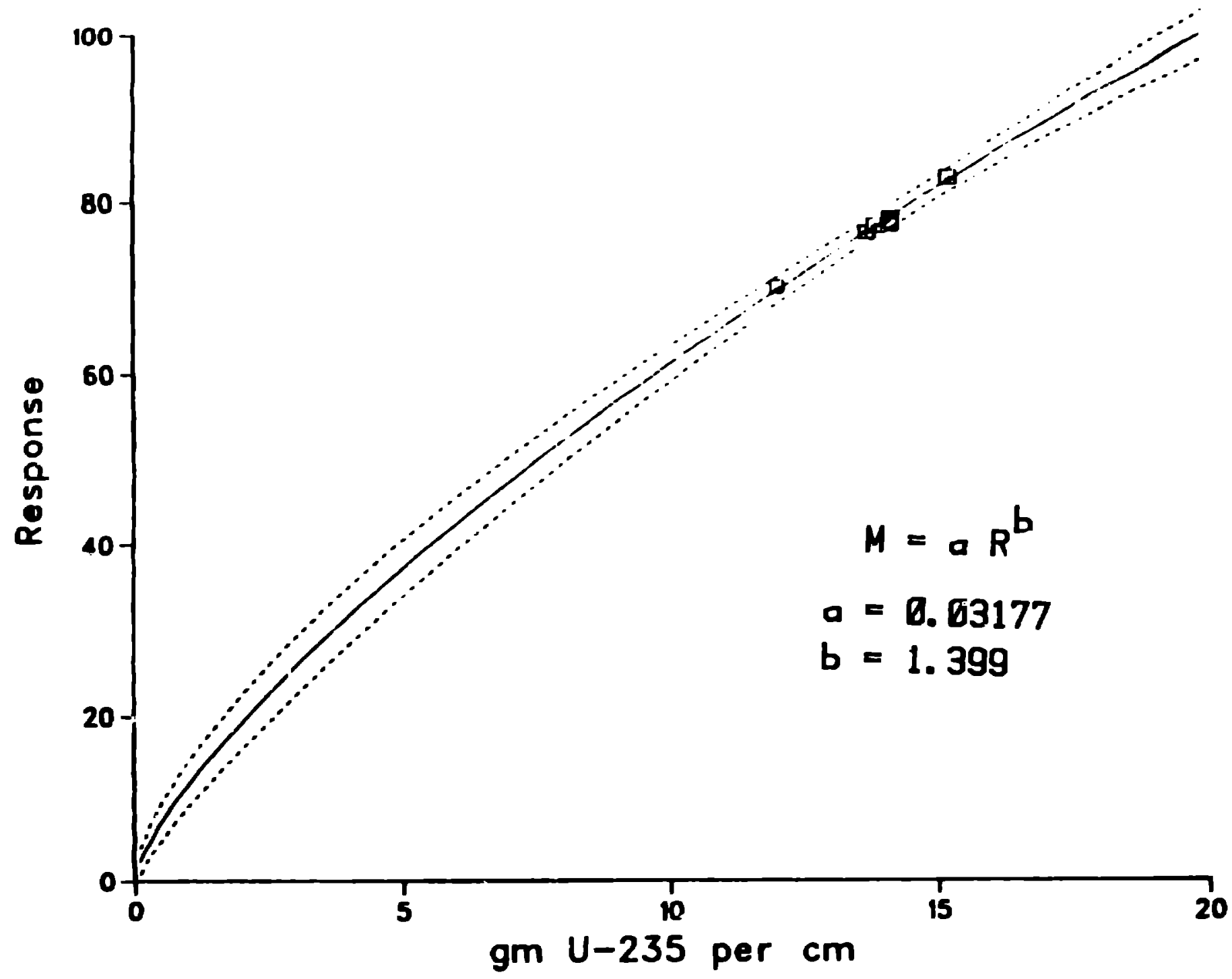

Fig. 7. Poner function calibration curve for BWR fuel assemblies showing $95 \%$ confidemie Iimits. 